\title{
IMMUNOLOGICAL ASPECTS OF RHEUMATOID DISEASE: A REVIEW
}

\author{
BY \\ L. E. GLYNN AND E. J. HOLBOROW \\ Rheumatism Research Unit (Medical Research Council), Canadian Red Cross Memorial Hospital, \\ Taplow, Maidenhead, Berkshire, England
}

\section{(1) INTRODUCTION}

The methods by which tissue damage may result from an immunological reaction are mostly obscure. In considering the immunological aspects of rheumatoid disease, we have, therefore, first summarized known immunological reactions. We have then considered those features of rheumatoid disease which could be interpreted as being based on similar reactions. Finally, we have discussed whether the parallel is sufficiently close to justify the acceptance of rheumatoid arthritis as an autoimmune reaction.

In the present state of knowledge of immunology, three qualitatively different types of basic response to specific antigenic stimuli are recognizable. These responses, which may occur either separately or together, are (1) the production of "classical" circulating precipitating antibody, (2) the production of circulating skin-sensitizing antibody (reagin), and (3) the tuberculin-type of delayed hypersensitivity, in which serum antibody is not involved.

\section{(2) Nature and Source of Antibody}

It has been known for a long time that the circulating antibodies of immune serum are found in the globulin fraction. Purified antibody globulin appears to differ little from "normal" serum globulin with regard to molecular weight, iso-electric point, or other physico-chemical properties; by salting-out methods, or by zone-electrophoresis for example, the immunologically active serum proteins are usually found in the gamma-globulin fraction, and analysis of chemical structure has shown no differences, in the terminal amino-acid sequences at any rate, between immunologically active and inert gamma globulin (Porter, 1950). The gamma globulin fraction of serum, however, is heterogeneous, and includes both low molecular weight (about 160,000) and high molecular weight
$(1,000,000)$ globulins, which may be separated in the ultracentrifuge as fractions with differing Svedberg sedimentation constants. In man, the commoner molecular size for antibody globulin corresponds to a sedimentation constant $\left(S_{20}\right)$ of $7 \mathrm{~S}$, but antibody activity (e.g. cold agglutinins, complete rhesus antibodies) is also found in the $19 \mathrm{~S}$ (macro globulin) fraction (Campbell, Sturgeon, and Vinograd, 1955). Electrophoresis, too, reveals heterogeneity of gamma globulins, based on differing mobilities of the molecules in an electric field, so that faster moving $(\gamma 1)$ and slower moving $(\gamma 2)$ components are demonstrable.

Circulating antibody has classically been detected by reactions with antigen leading to precipitation, agglutination or lysis of particles or cells, or toxin neutralization. In each case, the observable reaction is secondary to the primary union of antigen with antibody, and is determined by the particulate or cellular nature of the antigen (agglutination), by alteration of its biological properties (neutralization of toxic or enzymatic effect), or by a gross alteration in the physical state (precipitation) of both antigen and antibody brought about by their union. The detection of antigen-antibody reactions by complement fixation depends upon the inhibition of a similar gross change (haemolysis) in the sensitized red-cells of the indicator system. Circulating antibodies, however, may give rise to no directly observable reaction, and methods of modifying either antigen or antibody so as to render their reactions visible have been extensively developed. Examples of this are Boyden's method of coating tanned, red cells with protein antigens rendering them agglutinable by antibody (Boyden, 1951), and Coombs's antiglobulin test (Coombs, Mourant, and Race, 1945) for the detection of "incomplete" antibodies; and many other ingenious methods, notably Coons's fluorescent antibody method (Coons and Kaplan, 1950), have been developed in recent years. 
The second class of circulating antibody mentioned above includes the skin-sensitizing antibody encountered in hay-fever and other common allergies. This antibody differs from the classical precipitating type in that it is relatively labile at $56^{\circ} \mathrm{C}$., is difficult or impossible to detect by in vitro tests, and has a greater tendency to become fixed to tissue cells. The sera of most people with hayfever and asthma contain reagins of this character, which when injected into the skin of a normal recipient confer a localized change such that subsequent injection of the corresponding antigen into the site produces whealing and erythema comparable to that which occurs in the skin of the donor in response to the same antigen (the Prausnitz-Küstner reaction). Although there is a strong hereditary predisposition towards allergy and the production of the associated reagins, in serum sickness about 90 per cent. of all persons can produce a similar skin-sensitizing antibody with properties indistinguishable from reagin (Cooke and Spain, 1929).

While most of the identifiable fractions of the serum are produced in the liver, the production of gamma-globulin is mediated by mesenchymal cells, principally in the lymph nodes and spleen (see the review by McMaster, 1953). In experimental work, the route of administration of antigen has an important influence on the distribution of cells activated to produce antibody. Thus intravenous injection of antigen into rabbits leads to hyperplasia and antibody-producing activity in the cells of the red pulp of the spleen (Fagraeus, 1948), while the first result of intradermal inoculation (into the foot pad, for instance) is the production of antibody in the regional lymph nodes (McMaster, 1942). Using the fluorescent-antibody method to detect gammaglobulin in cells, Coons, Leduc, and Connolly (1955), and Ortega and Mellors (1957) have produced strong evidence in animals and man respectively to support the view that the plasma cell series in both splenic pulp and lymph nodes are important for gamma globulin production. White, Coons, and Connolly (1955) and Ortega and Mellors (1957) have also shown that in lymph nodes the "intrinsic" cells of the germinal centres are also apparently capable of gamma globulin production. In contrast, the conclusive demonstration of antibody in lymphocytes is lacking, although good evidence (e.g. Chase, $1951,1953)$ has been brought to show that lymphocytes are concerned with transport of antibody or transfer of ability to make it. Dixon, Weigle, and Roberts (1957), for example, have shown that transfer of suspensions of lymph node cells from immune animals to irradiated recipients can give rise in the latter to secondary responses of serum antibody. The relationship between macrophages, lymphocytes, and plasma cells developmentally and histologically is still a matter for dispute; but at present it seems justifiable to adopt the view of Burnet (1959), based on the suggestions of Taliaferro (1949), that mesenchymal cells with the inherent power of globulin production may, under appropriate conditions, take the form of stem cell, macrophage, lymphocyte, or plasma cell.

\section{(3) In vivo Immunological Reactions}

Idiosyncrasy, infection, or other contact with antigen may lead to hypersensitive responses based on immunological reactions. In experimental animals, a number of effects may be produced by antigenantibody reactions. These often closely resemble sensitivity states in man, and provide a basis for studying mechanisms of hypersensitivity.

(A) ANAPHYLAXIS.-The intravenous injection of an antigen into an animal already producing the corresponding circulating antibody usually gives rise after a brief interval to a generalized anaphylactic reaction. The symptoms vary with the species observed but are due to the release, following antigen-antibody interaction, of pharmacologicallo active substances (for example, histamine an serotonin), which alter the permeability of capilo laries, cause contraction of smooth muscle, and disturb clotting mechanisms. Although anaphylaxis is mediated by circulating antibody, passive transfer of immune serum to normal animals will not sensitize them anaphylactically to a challenging dose of antigen unless a sufficient time interval elapses between administration of antibody and antigen (Benacerraf and Kabat, 1949). In vitro, moreover, antigen will not release histamine from guinea-pig lung sensitized by incubation with appropriate rabbit antiserum unless this incubation period has been half an hour or more (Mongar and Schild, 1957). Globulin (at least from certain species) adsorbs on to tissues much more readily than, say, albumin (Humphrey, 1959), and it seems that such fixation of circulating antibody on to cell surfaces is probably necessary before union of antigen with antibody can give rise to significant pharmacological activity. This is consistent with of observations that histamine and serotonin are $N$ probably liberated from mast cells (Riley and West, 1953) and platelets (Hardisty and Stacey, 1955). Union of antigen and antibody may, in addition, activate other, non-cellular, systems - the esterase activity of complement, for example, and the proteolytic enzymes of blood (Lepow, Ratnoff, 
Rosen, and Pillemer, 1956; Ungar, 1953). The anaphylactic type of reaction is essentially, therefore, an immunologically induced transient pharmacological response and is modified considerably by antihistamine drugs.

(B) Arthus Reaction.-Circulating antibody, however, can give rise to another type of hypersensitivity - the Arthus reaction-which is slower in onset, and inflammatory in nature. If a depôt of antigen is introduced into the tissues of an immune animal (or conversely, if a depôt of antibody is passively introduced and antigen injected intravenously) then a state of affairs is created where there is a local excess of one reagent in the tissues, and of the other in the bloodstream. Their interaction in the vicinity of vascular tissue leads to the development of a cumulative rather than a transient reaction beginning within a few hours. This consists of the formation of thrombi of leucocytes and platelets in the small blood vessels in the area, often proceeding to localized infarction, with a characteristic vasculonecrotic reaction, and marked infiltration of polymorphonuclear cells. This Arthus reaction differs from the acute anaphylactic response in that (1) much more antibody is needed to give the minimum response, (2) antisera from species (e.g. horse) inert in passive transfer anaphylaxis tests may give positive Arthus reactions, and (3) only precipitating antibody is fully effective in the Arthus reaction. The latter, moreover, is unaffected by antihistamine drugs, but is much modified by steroids and salicylates. Some authors regard polyarteritis nodosa as an example of a generalized Arthus reaction (Waksman, 1959).

The Arthus reaction, unlike acute anaphylaxis, is principally a cellular response to antigen-antibody complexes, and Gell and Hinde (1954) have shown that in the active Arthus reaction there is a mononuclear cell infiltration underlying the acute inflammatory vasculo-necrotic damage, and particularly discernible in mild lesions obtained early in immunization. Both anaphylactic and Arthus hypersensitivity are dependent upon circulating (or fixed, but once circulating) antibody.

(C) Delayed Hypersensitivity (Tuberculin-Type). -A third type of hypersensitivity exists in which the dermal reaction to injected antigen in a sensitive individual is delayed; after several hours a progressive inflammatory reaction slowly develops and is maximal at 24-48 hours. This delayed response may be observed with protein antigens following thei intradermal injection, or with bacterial pro- teins following infection by the specific organism. The tuberculin reaction is a well known example. The characteristic features of the delayed response are (1) a predominance of mononuclear cells arranged in cuffs around the blood vessels at the site of the delayed skin reaction, (2) lack of transference of hypersensitivity to normal subjects by serum, and (3) successful transfer by cells from lymph nodes or buffy coat of sensitive individuals. Experimentally, Freund's oil-and-mycobacteria adjuvant (Freund, 1956) injected with antigens greatly enhances delayed hypersensitivity, presumably because the mononuclear histiocyte reaction evoked by mycobacteria favours this type of response to antigen. Pure delayed hypersensitivity in man or animals seldom occurs without accompanying circulating antibody, but recent work of Uhr, Salvin, and Pappenheimer (1957) has shown that, by using suitable immunizing techniques, delayed hypersensitivity to diphtheria toxoid may be obtained in man and guinea-pig without serum antibody being detected. These experiments, and the undoubted occurrence of delayed responses in agammaglobulinaemic patients (Good, Bridges, Zak, and Pappenheimer, 1959), underline the cellular nature of this hypersensitivity and its essential independence of circulating antibody.

(D) Iso-IMMUNITY.-The immunological responses considered so far have been those directed against frankly foreign antigens - that is to say antigens not intrinsically present in the body's own tissues. It is well known that individuals may react immunologically to tissues from other individuals even within the same species (iso-immunity). The blood group antigens (some of which occur in many tissues besides red cells) and their natural or immune iso-antibodies are an obvious example. The development or enhancement of iso-immunity by the body when it encounters incompatible red cell antigens (whether in transfusion or in pregnancy) is associated with manifestly harmful effects, attributable, it appears, entirely to the destructive action of circulating antibody on incompatible cells.

(i) Homograft Reaction.-There is another class of iso-immune reaction, however, which gives rise to equally striking biological effects, but which is mediated principally or exclusively by cellular responses to antigenic stimulation. The homograft reaction (see Medawar, 1958) is of this type. The transplantation of living tissue from one individual to another of the same species usually leads to destruction of the transplant within about a fort- 
night. A second graft from the same-but not from a different-donor is rejected characteristically more rapidly. The immunological nature of this so-called homograft reaction is demonstrated by the fact that this reactivity may be transferred from the graft recipient to normal individuals by lymph node and spleen cells. If a foreign graft is implanted in a host, but protected by a porous membrane allowing the passage of plasma but not of cells the graft remains undamaged (Algire, Weaver, and Prehn, 1954). The reaction of the host's tissues around the graft which accompanies its rejection is chiefly an infiltration of mononuclear cells. Both the cellular accompaniment of graft rejection and its tempo are much modified by steroids (Krohn, 1954), though not by antihistamines. In all these respects, therefore, the homograft reaction closely resembles a delayed hypersensitive response of the tuberculin type. Recent work (Brent, 1959) has corroborated this view by showing that antigenic tissue extracts from guinea-pig donors of skin grafts give rise to typical delayed skin reactions in recipient guineapigs which have already rejected grafts from the same donors. Moreover, lymph node cells from these same recipients injected back into the skins of their respective graft-donors give rise to similar delayed reactions on re-encountering the specific donor antigens in this way.

(ii) Specific Immune Tolerance.-The existence of iso-immunity is due to antigenic differences between individuals of the same species. Where no antigenic differences exist, no immunological consequences arise, as successful grafting between identical twins demonstrates. How, then, can the immunologically responsive cells of the body distinguish between "self" components and "nonself"? The phenomenon of immunological tolerance (vide infra) shows that this ability is acquired during foetal life. Billingham, Brent, and Medawar (1956) have shown that the introduction of living homologous tissue cells into the embryo before its immunological defence mechanism has become functionally mature leads after birth to acceptance and tolerance of skin homografts from the original cell donor, which in untreated animals would be rejected. That this tolerance of foreign tissue represents a central failure of the mechanism of immunological response is shown by Billingham, Brent, and Medawar, as follows:

If a CBA (inbred) strain mouse has been made tolerant of A-strain tissues by inoculation in foetal life with A-strain cells, then in adult life it will accept and carry an A-strain skin homograft. This graft can be readily destroyed and tolerance to A-strain tissue abolished by injecting the CBA-host with lymph node cells from a normal CBA-mouse actively immunized against A-strain tissue.

This shows that a tolerant mouse can "adopt" the immune mechanisms elaborated in a genetically $\overrightarrow{\vec{s}}$ identical but non-tolerant mouse. Therefore, a $\overline{0}$ tolerated homograft, as Medawar points out, 듬 survives because there is no reaction against it, not $\overline{\frac{\sigma}{3}}$ because any reaction is prevented from taking effect; it is treated by its host, in fact, as "self".

(E) Autormmunity.-Recognition of, and tolerance to, self, are clearly necessary conditions to the $\vec{\omega}$ avoidance of immunological responses involving self. Nevertheless, some body constituents may escape this recognition and tolerance. In lupus $\overrightarrow{0}$ erythematosus, for example, serum factors very like $\omega$ antibodies, with specificity for nuclear and cyto- $\vec{\omega}$ plasmic components, are commonplace (Dameshek, 1958); and antibodies to thyroglobulin and other 음 thyroid antigens are frequent in thyroid disease $\vec{C}$ (Roitt and Doniach, 1959). In the experimental $\mathbb{D}$ field, iso- and auto-antibodies to spermatozoa (Freund, Lipton, and Thompson, 1953), thyroid $\stackrel{\mathbb{}}{3}$ (Rose and Witebsky, 1956), and brain (Rivers, $\mathbb{D}$ Sprunt, and Berry, 1933) have been demonstrated in association with corresponding lesions induced by injecting these antigens with or without Freunds. adjuvant. It is clear, therefore, that the body mat fail to establish tolerance under certain conditions, or that already established tolerance may be broken. $\overline{0}$ Thus we may envisage, as Roitt and Doniach (1957) suggest, certain antigens such as thyroglobulin, $\stackrel{\unrhd}{\varrho}$ which are normally not available to the antibody- $\overrightarrow{\overrightarrow{0}}$ forming cells in foetal life, and against which $\frac{3}{3}$ tolerance is therefore never established. If, for any reason, leakage of these antigens occurs so that they come in contact with immunologically competent cells, then a specific immunological response occurs, as to any foreign antigen. On the other hand, failure of tolerance may be due to the emergence of immunologically competent cells capable of mediating specific reactions with certain body antigens.

The autoimmune conditions exemplified above $D$ could arise following either of these events. The former, where the antigen is only formally "self" N and could not previously have been encountered by the immune mechanism, requires no further $N$ explanation. The latter also exists, however, and $\mathrm{\omega}$ we have evidence for the occurrence of antibody? reacting with readily accessible antigens (in haemo-co lytic anaemia, for example) which compels us to consider how the mechanism for recognizing self $\stackrel{\oplus}{?}$ operates. 
Antibody production can scarcely be a simple matter of antigen imprinting its character on certain cells and thereby enforcing production of gamma globulin molecules bearing a complementary pattern, since this could explain neither the lack of antigenicity of body components nor the existence of tolerance phenomena. The persistence of antibody production for many years after antigenic stimulation (e.g. after some virus infections) and the differences between secondary and primary responses are also inconsistent with this concept. Instead of attributing a direct "template" activity to antigen, we can instead postulate (Jerne, 1955) that the gamma globulins in plasma form a population carrying all the reaction sites needed to react with any antigenic determinant, except those already existing in accessible components of the body. Further, we may postulate (Burnet, 1959) the existence of multiple clones of globulin producing mesenchymal cells, each responsible for one type of antibody globulin, and that this type is genetically determined. Antigen making contact with a cell capable of producing corresponding antibody stimulates proliferation of that cell, giving rise to a clone of daughter cells all producing the same specific antibody.

In this way antigenic stimulation could produce a specific response without direct determination of antibody configuration by antigen-by a process of selection of antibody. There are two further postulates necessary to this theory of Burnet's; the first is that somatic mutation of the genetic material of the antibody-producing cell is sufficiently frequent to give rise to the wide variety of globulin patterns required; the second is that, during development in embryonic life, the antibody-forming cells should pass through a transient phase of vulnerability to antigen, so that contact with it would result in death of the cell. If potential antigens persisted in sufficient. amount, their presence in tissue would eliminate all clones of cells with which they could react ("forbidden clones") and the non-antigenicity of body components would be achieved. This theory has been developed by Burnet (1959) from the hypothesis of Jerne (1955), with the object of providing a theoretical basis for autoimmunity. It postulates that autoimmunity can arise following somatic mutations in immunologically competent cells leading to the production of forbidden clones, and that owing to some anomaly, either mutational or environmental, the transient vulnerable stage of development does not occur, so that secondary stimulation leads to antibody production as in any other immunologically active clone.

While this clonal selection theory fits many of the facts of immunity, it is not readily susceptible to test. Nevertheless, it provides a working account of considerable value as a basis for investigation and research in the field of autoimmune disease.

\section{(4) Reactions in Rheumatoid Disease, POSSIBLY IMMUNOLOGICAL IN ORIGIN}

(A) Rheumatoid FACtoR.-Waaler (1940) and Rose, Ragan, Pearce, and Lipman (1948) independently discovered that the sera of the majority of patients with rheumatoid arthritis would agglutinate sheep cells sensitized with a subagglutinating dose of rabbit anti-sheep cell antiserum. As a result of the extensive work stimulated by these observations, it soon became clear that, for the purposes of the test, cells of many species could take the place of the sheep cells and that the rabbit antisera could be replaced by antisera of diverse animal origins. A multiplicity of modifications of the original test was subsequently developed to enhance its sensitivity (Ziff, 1957). Furthermore, fractionation of strongly-positive rheumatoid sera has demonstrated that the active principle, the rheumatoid factor, also has both the solubility and electrophoretic properties of a $\gamma$ globulin. Ultracentrifugal analysis, however, shows that it belongs to the category of macroglobulins with a sedimentation coefficient $\left(\mathbf{S}_{20}\right)$ of 19 as compared to a sedimentation coefficient of 7 for the bulk of normal $\gamma$ globulins (Franklin, Holman, Müller-Eberhard, and Kunkel, 1957a; Svartz, Carlson, Schlossmann, and Ehrenberg, 1958). In whole serum, however, each molecule of the rheumatoid factor exists in a loose combination with several molecules of $7 \mathrm{~S} \gamma$ globulin, forming a complex with sedimentation coefficient of 22 S (Franklin, Kunkel, Müller-Eberhard, and Holman, 1957b).

The further clarification of the Rose-Waaler reaction came from studies not only of the factor itself but of the material with which it reacts in positive tests, now referred to as the reactant. The precipitin reactions of rheumatoid sera reported by Epstein, Johnson, and Ragan (1956), and the ability of most rheumatoid sera to agglutinate inert particles such as latex (Singer and Plotz, 1956) or bentonite (Bozicevich, Bunim, Freund, and Ward, 1958) when coated with $\gamma$ globulin (e.g. human F.II), afford strong evidence that the reactant is in fact a $\gamma$ globulin.

The three outstanding problems concerning the rheumatoid factor that remain to be considered are:

(i) Is the rheumatoid factor an antibody and its reaction with $\gamma$ globulin an antigen antibody reaction? 
(ii) Is the reactant a normal $\gamma$ globulin or must it first be altered in some special way?

(iii) What role, if any, does the factor play in the pathogenesis of the disease?

Although the majority of antibodies are $\gamma$ globulins of the $7 \mathrm{~S}$ category, several antibodies are known, both natural and acquired, that belong to the $19 \mathrm{~S}$ group of $\gamma$ globulins (Franklin and Kunkel, 1957). The antibody nature of the rheumatoid factor cannot, therefore, be excluded on the grounds of its high sedimentation coefficient. Similarly, although the majority of antigen antibody complexes are able to fix complement, the failure of the rheumatoid factor-reactant precipitate to do so does not prove the non-immune nature of the combination, since many authentic antigen antibody complexes are known which also lack this property. Even more characteristic of an antigen antibody reaction than complement fixation is the shape of the curve obtained when, in an antigen-antibody system, the amount of antibody precipitated is plotted against increasing amounts of antigen added. The decrease in the amount of precipitate obtained when the antigen is increased beyond that causing maximum precipitation is due, of course, to the solubility of antigen-antibody complexes in excess of antigen. The failure of the curve of precipitation between F.II and rheumatoid factor to conform to that of a typical antigen-antibody precipitation curve has been particularly stressed by Vaughan, Ellis, and Marshall (1958), and is undoubtedly a serious objection to the view that rheumatoid factor is an antibody to altered $\gamma$ globulin. However, although the inhibition of precipitation in the region of antigen excess is a striking feature of most precipitin systems, it is sometimes small or even absent (Wilson and Miles, 1955a). That it should be absent in the present system is indeed not entirely unexpected. It is presumably the presence of multiple hydrophilic groups in a protein antigen that are responsible for the phenomenon of solubility of an immune precipitate in antigen excess (Wilson and Miles, 1955b), and with heat denatured F.II we are undoubtedly dealing with a protein that has already lost the major part of its hydrophilic property by virtue of the process of denaturation.

Finally, antibody globulins are largely, if not exclusively, produced by plasma cells, and their presence can be clearly revealed by the use of fluorescent antibody applied to histological preparations pretreated with antigen. Mellors, Heimer, Corcos, and Korngold (1959), by applying this method and using heat-aggregated $\gamma$ globulin as the antigen, have clearly demonstrated that rheumatoid factor like true immune globulins is found in $\bar{\xi}$ typical plasma cells.

Largely because of the work of Kunkel and his colleagues, it is generally held that the reaction $\overrightarrow{\vec{s}}$ between the rheumatoid factor and reactant $\overline{0}$ requires no specific change in the latter, and this $\frac{\square}{\sigma}$ view is supported by the observation that in whole $\frac{\bar{\sigma}}{\bar{c}}$. serum the factor exists as a complex with presumably $\widehat{\nabla}$ normal $7 \mathrm{~S} \gamma$ globulin. Kunkel's own observation, that the Epstein precipitin reaction is greatly o increased by heating the reactant to $63^{\circ} \mathrm{C}$. for $\vec{\circ}$ 10 minutes, is interpreted as indicating nothing $\vec{\overrightarrow{ }}$ more than that the heat aggregated material is more readily precipitable than the non-aggregated material. If this be true, however, it is difficult ? to see why, for example, the rheumatoid factor $\overrightarrow{0}$ which in whole serum is already bound to $7 \mathbf{S} \gamma \omega$ globulin should exchange this for $\gamma$ globulin $\overrightarrow{0}$ aggregated by heat or specifically absorbed on to an $\mathrm{O}$ antigenic surface as in the sensitized sheep cell test. $\stackrel{ }{-}$ That such an exchange does actually take place has $\vec{s}$ been elegantly shown by Christian (1959). He $\frac{\mathbb{O}}{O}$ found that, when rheumatoid factor of $22 \mathrm{~S}$ separ- $\overrightarrow{\mathbb{D}}$ ated by ultracentrifugation is made to precipitate $\bar{z}$ with $7 \mathbf{S} \gamma$ globulin previously aggregated by heat, the $\stackrel{\oplus}{-}$ $7 \mathrm{~S}$ fraction originally bound to the $19 \mathrm{~S}$ fraction $8 \overrightarrow{0}$ progressively liberated into the supernatant as mo of the heat-aggregated globulin is added.

A technical modification known as the inhibita test was introduced by Ziff, Brown, Lospalluto, Badin, and McEwen (1956). The basis of this test is the presence in normal serum of a factor capable of inhibiting the agglutination of sensitized sheep cells by rheumatoid sera and the absence of this factor from the serum of patients with rheumatoid arthritis. It was claimed for this test that rheumatoid sera too weak in the rheumatoid factor to give a positive agglutination titre with sensitized cells could still be detected because of the absence of inhibitor. Undoubtedly by this means a considerable increase of sensitivity was attained. Unfortunately, in the hands of most other investigators, this was matched by a corresponding fall in specificity. Recently a similar modification of the latex particle agglutination test has been intro- $\frac{7}{0}$ duced (Dresner and Trombly, 1959), which is also based on the absence of inhibitor from rheumatoid $N$ sera, and shows a comparable gain in sensitivity and $N$ loss of specificity. A study of the patients that gave a false positive reaction with this test, however, $\mathcal{O}$ showed that the great majority were suffering from a virus infection, syphilis, or some hepatic disease, $\stackrel{\varrho}{=}$ i.e. from conditions which usually offer little con- $\stackrel{\mathcal{D}}{\rightarrow}$ fusion with rheumatoid arthritis. A positive latex-? inhibition test, therefore, in a patient from whom 
these diseases can be excluded is indicative of rheumatoid arthritis with a probability of almost 100 per cent.

Since reactant $\gamma$ globulin may be obtained from a wide variety of animal species, it is necessary to postulate a high degree of non-specificity in the reaction with rheumatoid sera, and, since immunological specificity of a protein is largely determined by its tertiary configuration, i.e. the coiling of the helical peptide chains, the most economical hypothesis to explain these facts is that advanced by us in 1957 (Glynn, Holborow, and Johnson, 1957). We then suggested that the rheumatoid factor is an antibody specifically directed against antigenic groups shared by many species of $\gamma$ globulin and exposed when the native proteins become unfolded either by heat, or by specific interaction with an antigenic surface, or on non-specific adsorption by certain non-antigenic surfaces such as latex or bentonite.

Since some degree of denaturation of $\gamma$ globulin must be a frequent occurrence both in man and animals, the antigenic activity of such denatured globulin must be presumed to be enhanced in rheumatoid subjects. In other words, according to our hypothesis, the presence of rheumatoid factor in any individual implies the ability of the immune mechanisms of that individual to recognize as foreign the altered autogenous $\gamma$ globulin, whilst normal individuals without rheumatoid factor lack this ability. That is to say that the rheumatoid subject is apparently capable of recognizing, and therefore regarding as foreign, a degree of change in an autogenous protein that is ignored by the immunological mechanism of normal individuals.

The Gm groups described by Grubb (1958) appear to support this conclusion, although he himself does not regard the rheumatoid factor as an antibody. Briefly, if human Group O Rhesus D positive cells are sensitized with certain human sera containing incomplete anti-D, they can be agglutinated by some rheumatoid sera. Human sera can then be divided into two groups according to their ability, or inability, to inhibit this system. The inhibitory sera are designated $\mathrm{Gm} \mathrm{a}+$, the noninhibitory $\mathrm{Gm} \mathrm{a}-$. The inhibitory activity in the $\mathrm{Gm} \mathrm{a}+$ sera has been shown to be present in the $\gamma$ globulin fraction. If the agglutination of the sensitized D-positive cells is indeed an immunological reaction, it is apparent that certain rheumatoid sera, themselves either $\mathrm{Gm} \mathrm{a}+$ or -, can distinguish two genetically determined varieties of human $\gamma$ globulin.

The role of the rheumatoid factor in pathogenesis is difficult to assess. There is no strong correlation between the amount of factor and clinical severity, but a positive correlation has been established with the duration of the disease and especially with the presence of subcutaneous nodules (Ball, 1952; Jacobson, Kammerer, Wolf, Epstein, and Heller, 1956). Attempts to demonstrate a pathogenic effect of the factor by administration of high titre sera (Vaughan and Harris, 1959) or an ameliorating effect by sera rich in inhibitory factor have been uniformly unsuccessful (Ziff and others, 1956). Neither of these experiments should be taken as convincing evidence that the factor is without pathogenic effect, since the quantitative differences between passive administration and active formation must be considerable.

(B) L.E.-Cell Phenomenon, And Anti-nuclear AND ANTI-CYTOPLASMIC FACTORS.-A second serum factor of immunological significance found in some cases of rheumatoid arthritis is that responsible for the L.E. cell phenomenon, first described by Hargraves, Richmond, and Morton (1948) in cases of disseminated lupus erythematosus. In that disease many patients possess in their serum a $\gamma$ globulin of the $7 \mathrm{~S}$ variety that is capable of inducing the nuclear changes and phagocytosis that result in the typical L.E. cell (Haserick and Bortz, 1949). The incidence of this substance in cases of rheumatoid arthritis varies considerably with the technique used for its demonstration, but it is variously estimated as between one (Ishmael, 1955) and 17 per cent. (Kievits, Goslings, Schuit, and Hijmans, 1956). In disseminated lupus erythematosus and in rheumatoid arthritis, the presence of the L.E.-cell factor is usually associated with other $\gamma$ globulins capable of reacting with various nuclear constituents but nevertheless incapable themselves of inducing the formation of typical L.E. cells (Robbins, Holman, Deicher, and Kunkel, 1957). These interactions include precipitation and complement fixation with desoxyribonucleoprotein or desoxyribonucleic acid. The presence of these various proteins in the $7 \mathrm{~S} \gamma$ globulins, the fixation of complement and the shape of the various precipitin curves (Deicher, Holman, and Kunkel, 1959) leave little doubt that these various factors must be regarded as true antibodies and their reactants as antigens or haptens. With regard to the L.E.-cell phenomenon itself, the nature of the reactant is presumably DNA histone, since the factor can only be absorbed by whole nuclei or native DNA histone (Hijmans and Schuit, 1958), but not by DNA or free histone. Until recently the change undergone by the phagocytosed nucleus in typical L.E. cells was regarded as a depoly- 
merization of its desoxyribonucleoprotein. This view was based upon the weakness of its staining with methyl green relative to the strength of the Feulgen reaction. The work of Godman and Deitch (1957), however, has clearly shown that the weakness of the staining with methyl green is not due to depolymerization but to substitution of histone by some other protein more firmly bound to the DNA. Normally, staining with methyl green is apparently brought about by displacement of histone by the dye. In the L.E. cell the weaklybound histone is partly displaced by other proteins more firmly bound. It seems highly probable, although not yet proven, that this firmly bound protein is the L.E.-cell factor itself.

A phenomenon related to that of the L.E. cell and described by Friou, Finch, and Detre (1958) and by Holborow, Weir, and Johnson (1957) is the ability of L.E. sera and some rheumatoid sera to react with nuclei in tissue sections, the reaction being subsequently revealed by staining with a fluorescent rabbit anti-human $\gamma$ globulin antiserum. The failure of this so-called anti-nuclear factor to react with guinea-pig spermatozoa, although reacting strongly with the spermatogonia and spermatids, suggests that histone plays some essential role (Holborow and Weir, 1959). Since the antinuclear factor does not react with either DNA or histone when free, nor with nucleo-proteins consisting of DNA and protamine, it has been suggested that the reactant is histone but only when a specific configuration has been impressed upon it by its union with DNA (Editorial, 1959). This view receives support from the observation that the DNA can be removed enzymatically from nuclei pretreated with anti-nuclear factor without impairing the subsequent staining by fluorescent anti-globulin (Holborow, 1960). Reactions capable of fixing complement have not only been described between serum proteins and nuclear constituents but also, although less frequently, with cytoplasmic constituents. These include mitochondria, microsomes, and soluble cellular protein (Asherson, 1960). As with the nuclear reactions, the majority of patients giving these cytoplasmic reactions are suffering from disseminated lupus erythematosus.

(C) Haemolytic Anaemia and Leucopenia.-The two serum factors considered above do not appear to be directly responsible for any of the known lesions of rheumatoid arthritis. On the other hand, there are several lesions commonly found in this disease for which there is a strong possibility that circulating antibodies play an important causative role despite the difficulty usually encoun- tered in demonstrating their presence. For example, leucopenia is common in rheumatoid arthritis and on some occasions has been associated with apparently specific antibodies, detected by a Coombs consumption test (van Loghem, van der Hart, Hijmans, and Schuit, 1958).

Anaemia, also a common finding in rheumatoid arthritics, has not yet been shown to be associated with an autoimmune mechanism, but its many clinical features (McCrea, 1957) strongly suggest the participation of an underlying autoimmunity. The frequency with which leucopenia, anaemia, and thrombocytopenia occur in disseminated lupus erythematosus associated with specific autoantibodies suggests that a similar mechanism may well underlie these same phenomena in rheumatoid arthritis.

(D) Vascular Lesions. - The incidence and significance of the vascular lesions in rheumatoid arthritis has received considerable attention in recent years. A question of major clinical significance is the role of corticosteroid therapy in the apparent increase in the incidence of arteritis (Kemper, Baggenstoss, and Slocumb, 1957). Since comparable vascular lesions undoubtedly occurred inf rheumatoid arthritis before the era of cortico steroid therapy, the lesions cannot be regarded as exclusively iatrogenic. The effective use of cortico? steroids in suppressing immunological reactions and their apparent failure to influence favourably the arteritis of rheumatoid arthritis could be regarded as evidence against an immune pathogenesis of the vascular damage. The corticosteroids, however, have profound metabolic effects quite apart from those they exert on immunity. For example, the adverse effects of hypertension resulting from the corticosteroids might well outweigh any advantages obtained from their immunological effects. The ready production of an acute necrotizing arteritis in experimental animals by immunological methods, such as the repeated injection of foreign serum (Rich and Gregory, 1943), and the finding of similar lesions in man in comparable circumstances (Rich, 1942) certainly encourages the view that the vascular lesions of rheumatoid arthritis have a similar immune pathogenesis. Here it is perhaps important to differentiate two types of immunological reaction that can be used to produce an experimental vasculitis. With the most commonly practised experimental method, namely the intravenous injection of large amounts of foreign antigen, the lesion is apparently the result of the interaction of antigen and antibody within the vessel wall. It has, however, proved possible to produce vas- 
cular lesions by the injection of sera containing specific antibodies to antigens naturally present in the particular vessels in question, e.g. the injection into guinea-pigs of an anti-Forssman antibody prepared, say, in rabbits (Tanaka and Leduc, 1956). Although in rheumatoid disease either of these two mechanisms seems possible, there is not at present any convincing evidence of specific antivascular antibodies in human subjects. It is, however, conceivable that the interaction of the rheumatoid factor with its reactant could take place in the vessel wall in the same way as specific antibody and foreign serum antigens interact in the experimental animal.

(E) SJÖgREN's SYNDROME.-Yet another clinical feature shown by a significant proportion of rheumatoid arthritics for which an immunological basis has recently been suggested is the dryness of the mouth and grittiness of the eyes now usually referred to as Sjögren's syndrome. In this condition the lacrimal and salivary glands show atrophic changes of the parenchyma accompanied by a variable degree of cellular infiltration consisting mainly of plasma cells and lymphocytes. The similarity of the histological picture to that of the thyroid in Hashimoto's disease was indeed commented upon some years before the immunological features of this disease had been recognized (Cardell and Gurling, 1954). It must be admitted that at present the evidence in favour of an immunological pathogenesis is suggestive rather than convincing. Jones (1958) studied sera for the presence of precipitins by immuno-diffusion against an extract of lacrimal gland, and found only one clearly positive. To account for the high proportion of negative results, however, it was pointed out that these were all from cases of long standing, in which presumably the complete destruction of the gland had led to the loss of any further antigenic stimulation, and hence to the disappearance from the serum of demonstrable antibody. Heaton (1959) has recently reported the finding of L.E. factor in the serum of ten cases of Sjögren's syndrome out of 28 studied. In the absence of the criteria used for the recognition of an L.E. cell, it is impossible to assess the significance of this observation, and in view of the incidence of the L.E.-cell phenomenon in rheumatoid arthritis cannot be accepted as proof that Sjögren's syndrome is a feature of disseminated lupus erythematosus. Attempts by us to demonstrate a circulating antibody in the serum of four patients with the syndrome by means of the Coon's sandwich technique have been unsuccessful. It is evident that conclusive evidence of the immune pathogenesis of Sjögren's syndrome is still lacking.

(F) Subcutaneous Nodules.--The subcutaneous nodules so characteristic of rheumatoid arthritis have much in common histologically with the granulomata of other specific diseases such as tuberculosis and syphilis. To what extent the infective granulomata owe their characteristic features to an immunological reaction to the causative agents is still a moot point, but until recently there was little evidence implicating immunological participation in the development of the rheumatoid nodule, despite the demonstration, by immuno-fluorescent staining, of the presence within the nodule of $\gamma$ globulin (Vazquez and Dixon, 1957), and the positive correlation between the presence of nodules and the rheumatoid factor in the serum. Evidence more suggestive of an underlying immunological abnormality has been adduced by Banerjee and Glynn (1960) from a study of the reactions of experimental animals to implants of fibrin from their own or other species. With homologous fibrin, invasion by fibroblasts and capillaries was rapid, and within 2 to 4 weeks, depending upon the size of the implant, the fibrin was completely replaced by a small fibrous scar. With heterologous fibrin implants, the reaction was similar to that with homologous fibrin for the first 5 to 7 days. From then on the difference was striking: the fibroblasts that had penetrated the fibrin underwent necrosis, whilst those at the periphery arranged themselves at right-angles to the surface of the implant to form a palisade strikingly reminiscent of that seen in a rheumatoid nodule. The peripheral vascular formations, with their associated infiltrations of lymphocytes, histiocytes, and plasma cells, contributed to the remarkable similarity between the experimental lesion and a typical rheumatoid nodule.

Several features of the reaction to the foreign fibrin implants suggested that the differences from the reaction to homologous fibrin were due to the antigenicity of the foreign fibrin. Thus the latent period between the time of implantation and the appearance of the characteristic reaction is presumably required for the stimulation and reaction of the immune mechanisms of the host. Plasma cells, known to be associated with immune reactions and engaged in the synthesis of specific antibodies were conspicuous in the host tissues in the vicinity of the implant and indeed circulating antibody against fibrinogen of the donor species could be demonstrated. Furthermore, the repetition of the implant some weeks after a primary implantation leads to an 
accelerated response, and finally such an accelerated reaction may show an acute necrotizing arteritis similar to that produced by massive injections of foreign serum.

It is, of course, at this stage impossible to say to what extent the similarity between the natural and the experimental "nodules" are due to similarities in their pathogenesis. The presence of $\gamma$ globulin in the rheumatoid nodule and the correlation between the presence of nodules and rheumatoid factor in the serum do, however, encourage the view that the similarities will not prove entirely fortuitous.

\section{(5) Discussion}

Despite the growing volume of evidence implicating disturbances of immune mechanisms in the pathogenesis of the rheumatoid diseases, the recent observation of the frequency of these diseases among patients with congenital agammaglobulinaemia (Gitlin, Janeway, Apt, and Craig, 1959) has shown that circulating antibody and indeed the plasma cells that give rise to it cannot play the fundamental pathogenetic role. It must, however, be realized that, even in congenital agammaglobulinaemia, the absence of $\gamma$ globulins is rarely absolute and the use of sensitive immunological tests usually reveals small amounts to be present. Furthermore, antibodies are not confined exclusively to this group of proteins. Several occur in both the $\alpha$ and $\beta$ fractions (Cann, 1959). Finally, several incontrovertibly immune reactions, e.g. the tuberculin reaction, are unrelated to the presence of circulating antibody and cannot in consequence be transferred passively by serum proteins. On the contrary, they are mediated by certain cells of the lympho-reticular system and can be readily transferred passively by the cells of this system. It is probable, therefore, that if an immune mechanism underlies the development of rheumatoid disease it is a mechanism more akin to that responsible for the delayed, than for the immediate, type of hypersensitivity. The extensive production of experimental lesions of the brain (Kabat, Wolf, and Bezer, 1947), thyroid (Witebsky and Rose, 1956), testis (Freund and others, 1953), and adrenal (Colover and Glynn, 1958), by what appear to be autoimmune mechanisms has produced results in harmony with this view. In each of these examples the actual damage is apparently mediated by cells and not by circulating antibody. Even in those experimental animals in which a circulating antibody can be demonstrated, it has never been shown that the antibody is responsible for the lesions, and on some occasions at least it has been suspected that these circulating antibodies might even exert a protective function (Florey, cited by Vulpé, 1959). ․ㅡㅇ. In this group of experimental diseases the mechanism? is therefore more akin to the delayed type of reaction. $\stackrel{\vec{F}}{\overrightarrow{2}}$ It differs, however, from the tuberculin reaction in that the appropriate lesions cannot be induced by등 a simple transference of lymphocytes from affected $\overline{\bar{m}}$. to normal animals. The difference, however, is not $\mathbb{Q}$ fundamental but presumably due to the necessary survival period of the transferred cells. With ${ }^{\infty}$ transference of tuberculin sensitivity, survival of the $\vec{O}$ transferred cells is not necessary. With transference of experimental allergic encephalitis, how- $\omega$ ever, the importance of adequate survival of the transferred cells has been clearly shown by Paterson? (1960). He had found, in accordance with other $\overrightarrow{0}$ workers, that the transfer of a suspension of lymph node cells from a donor with experimental allergic $\vec{\theta}$ encephalitis to a recipient even of the same strain ${ }^{\circ}$ did not result in the transfer of the disease. If, however, the recipient had been rendered tolerant $\bar{c}$ of the donor's cells by a cell transfer from the donor $\mathbb{D}$ at about the time of birth of the recipient, transfer $\bar{D}$ of the allergic encephalitis could be successfully achieved.

It is now well over a decade since the possibiligy $\vec{\bullet}$ that rheumatoid arthritis is an autoimmune disease? has been seriously considered. The evidence 通favour of it, and largely acquired during that periout, falls into two groups:

(1) Certain properties of the serum are strongly suggestive of the presence of an antibody capable $\stackrel{\mathcal{Q}}{\Omega}$ of reacting with host antigens such as aggregated $\stackrel{\varrho}{\rightleftharpoons}$ $\gamma$ globulin or various nuclear and cytoplasmic components;

(2) Some of the lesions of rheumatoid arthritis have much in common with experimental lesions? induced by immunological procedures. These include the arteritis and nodule formation. Furthermore, the plasma cell, now generally accepted as the main source of immune $\gamma \cdot$ globulin, is the characteristic cell of the histology of rheumatoid lesions.

It is apparent from the available evidence that the hypothesis that rheumatoid arthritis is an auto-o immune disease is still far from proven. The only convincing proof would be the transference of the $\mathrm{F}$ disease by living lymph node cells to a recipient $N$ tolerant to these, i.e. the human equivalent of $\mathrm{W}^{-}$ Patterson's method for the transmission of allergic ${ }_{\sigma}$ encephalitis in guinea-pigs. Even if ethically justifiable, such an experiment could at present $\frac{0}{\mathbb{C}}$ only be performed with identical twins. Assuming, however, a successful outcome of such an experi- ment, we should still lack the fundamental know- 
ledge how and why this basic change had occurred in the immunological mechanism of the rheumatoid patient. Until we pass from the phase of speculation to the phase of facts concerning immunological tolerance and the recognition of self, we shall remain unable to understand the nature of that fundamental disturbance that must underlie all diseases of an autoimmune kind, namely the breakdown of the mechanism of self recognition. An essential prerequisite for such an understanding is of course the elucidation of the means by which cells with the potential for antibody production normally avoid the elaboration of autoantibodies. It is conceivable that common to all the possible antigens in any individual is a unique self-marker, which is in some way responsible for the failure of immune response by cells of the same individual, themselves endowed with the same self-marker. Simpler to comprehend is the view recently put forward by Burnet (1957) that accounts for the normal absence of autoimmune reactions not by self-markers but by the elimination during foetal or early post-natal life of those cells capable of reacting with self antigens. The reappearance of such cells in patients with autoimmune disease is accounted for by a somatic mutation of some of the cells of the antibody forming system. Such mutations are an essential feature of Burnet's hypothesis and the appearance of cells capable of forming autoantibodies should therefore be a common occurrence. The rarity of the diseases attributable to autoimmunity therefore requires a homeostatic mechanism for the elimination of such undesirable mutants. According to this hypothesis, therefore, the development of autoimmunity results from the breakdown of this homeostatic mechanism.

Although, therefore, the role of autoimmunity in the pathogenesis of rheumatoid disease must still be regarded as hypothetical, the stimulus that this concept has provided has been immeasurable and the features of the disease discussed above are not without encouragement to the proponents of the autoimmune hypothesis.

\section{Summary}

The various immunological reactions reproducible experimentally in animals or man have been discussed. These include anaphylaxis, the Arthus reaction, delayed hypersensitivity of the tuberculin type, and the homograft reactions. Lesions (e.g. the subcutaneous nodule) and serological reactions (e.g. the Rose-Waaler test) are then considered in the light of these known immunological reactions, from which it is concluded that autoimmune phenomena are probably of significance in the pathogenesis of rheumatoid disease.

\section{REFERENCES}

Algire, G. H., Weaver, J. M., and Prehn, R. T. (1954). J. nat. Cancer Inst., 15, 493.

Asherson, J. (1960). Personal communication.

Ball, J. (1952). Ann. rheum. Dis., 11, 97.

Banerjee, S. K., and Glynn, L. E. (1960). Proc. nat. Acad. Sci. (Wash.). (In the press.)

Benacerraf, B., and Kabat, E. A. (1949). J. Immunol., 62, 517.

Billingham, R. E., Brent, L., and Medawar, P. B. (1956). Phil. Trans. $B, 239,357$.

Boyden, S. V. (1951). J. exp. Med., 93, 107.

Bozicevich, J., Bunim, J. J., Freund, J., and Ward, S. B. (1958). Proc. Soc. exp. Biol. (N.Y.), 97, 180.

Brent, L. (1959). In "Mechanisms of Hypersensitivity" (Henry Ford Hospital International Symposium), ed. J. H. Shaffer, G. A. LoGrippo, and M. W. Chase, p. 555. Little, Brown and Co., Boston; Churchill, London.

Burnet, F. M. (1957). Aust. J. Sci., 20,67.

(1959). "The Clonal Selection Theory of Acquired Immunity", p. 46. University Press, Cambridge.

Campbeil, D. H., Sturgeon, P., and Vinograd, J. R. (1955). Science, 122, 1091 .'

Cann, J. R. (1959). In "Immunity and Virus Infection: Symposium held at Vanderbilt University School of Medicine, May, 1958", ed. V. A. Najjar, p. 100 . Wiley, New York.

Cardell, B. S., and Gurling, K. J. (1954). J. Path. Bact., 68, 137.

Chase, M. W. (1951). Fed. Proc., 10, 404 . Response: A Symposium held at the New York Academy of Medicine, March, 1951" (Section on Microbiology, Symposium No. 5), ed. A. M. Pappenheimer, p. 156. Columbia University Press, New York.

Christian, C. L. (1959). Arthr. and Rheum., 2, 289.

Colover, J., and Glynn, L. E. (1958). Immunology, 1, 172.

Cooke, R. A., and Spain, W. C. (1929). J. Immunol., 17, 295.

Coombs, R. R. A., Mourant, A. E., and Race, R. R. (1945). Lancet, 2,15 .

Coons, A. H., and Kaplan, M. H. (1950). J. exp. Med., 91, 1.

, Leduc, E. H., and Connolly, J. M. (1955). Ibid., 102, 49.

Dameshek, W. (1958). Ann. intern. Med., 48, 707.

Deicher, H. R. G., Holman, H. R., and Kunkel, H. G. (1959). J. exp. Med., 109, 97.

Dixon, F. J., Weigle, W. O., and Roberts, J. C. (1957). J. Immunol., $78,56$.

Dresner, E., and Trombly, P. (1959). New Engl. J. Med., 261, 981.

Editorial (1959). Lancet, 1, 823.

Epstein, W., Johnson, A., and Ragan, C. (1956). Proc. Soc. exp. Biol.' (N.Y.), 91, 235 .

Fragraeus, A. (1948). Acta med. scand., 130 (Suppl. 204).

Florey, E. (1959). Cited by Vulpé, M., "Allergic Encephalomyelitis". Thomas, Springfield, III.

Franklin, E. C., Holman, H. R., Müller-Eberhard, H. J. and Kunkel H. G. (1957a). J. exp. Med., 105, 425.

- and Kunkel, H. G. (1957). J. Immunol., 78, 11

,$- \ldots$, Müller-Eberhard, H. J., and Holman, H. R. (1957b). Ann. rheum. Dis., 16, 315.

Freund, J. (1956). Fortschr. Tuberk.-Forsch., 7, 130.

Lipton, M. M., and Thompson, G. E. (1953). J. exp. Med., 97, 711 .

Friou, G. J., Finch, S. C., and Detre, K. D. (1958). J. Immunol., $80,324$.

Gell, P. G. H., and Hinde, I. T. (1954). Int. Arch. Allergy, 5, 23.

Gitlin, D., Janeway, C. A., Apt, L., and Craig, J. M. (1959). In "Cellular and Humoral Aspects of the Hypersensitive States: A Symposium held at the New York Academy of Medicine" (Section on Microbiology, Symposium No. 9), ed. H. S. (Section on Microbiology, Symposium No. 9), ed. H.
Lawrence, p. 425. Hoeber, New York; Cassell, London.

Lawrence, p. 425. Hoeber, New York; Cassell, London.
Glynn, L. E., Holborow, E. J., and Johnson, G. D. (1957). Proc. roy. Soc. Med., 50, 469.

Godman, G. C., and Deitch, A. D. (1957). J. exp. Med., 106, 575.

Good, R. A., Bridges, R. A., Zak, S. J., and Pappenheimer, A. M. (1959). In "Mechanisms of Hypersensitivity" (Henry Ford Hospital International Symposium), ed. J. H. Shaffer, G. A. LoGrippo, and M. W. Chase, p. 467. Little, Brown and Co., BoGrippo, and M. W. Chase,

Boston; Churchill, London.
Grubb, R. (1958). Acta haemat. (Basel), 20, 246.

Hardisty, R. M., and Stacey, R. S. (1955). J. Physiol. (Lond.), 130, 711 .

Hargraves, M. M., Richmond, H., and Morton, R. (1948). Proc. Mayo Clin., 23, 25.

Haserick, J. R., and Bortz, D. W. (1949). Cleveland Clin. Quart., 16, 158.

Heaton, J. M. (1959) Brit. med. J., 1, 466.

Hijmans, W., and Schuit, H. R. E. (1958). Vox Sang. (Basel), 3, 184.

Holborow, E. J. (1960). Proc. roy. Soc. Med., 53, 625. 
Holborow, E. J., and Weir, D. M. (1959), Lancet, 1, 809

- and Johnson, G. D. (1957) Brit med J 2, 732

Humphrey, J. H. (1959). In "Cellular and Humoral Áspects of the Hypersensitive States: A Symposium held at the New York Academy of Medicine" (Section on Microbiology, Symposium No. 9), ed. H. S. Lawrence, p. 7. Hoeber, New York; Cassell, London.

Ishmael, W. K. (1955). Ann. rheum. Dis., 14, 415

Jacobson, A. S., Kammerer, W. H., Woif, J., Epstein, W. V., and Heller, G. (1956). Amer. J. Med., 20, 490.

Jerne, N. K. (1955). Proc. nat. Acad. Sci. (Wash.), 41, 849

Jones, B. R. (1958). Lancet, $2,773$.

Kabat, E. A., Wolf, A., and Bezer, A. E. (1947). J. exp. Med., 85, 117.

Kemper, J. W., Baggenstoss, A. H., and Slocumb, C. H. (1957). Ann. intern. Med., 46, 831 .

Kievits, J. H., Goslings, J., Schuit, H. R. E., and Hijmans, W. (1956). Ann. rheum. Dis., 15, 211.

Krohn, P. L. (1954). J. Endocr., 11, 71, 78.

Lepow, I. H., Ratnoff, O. D., Rosen, F. S., and Pillemer, L. (1956). Proc. Soc. exp. Biol. (N.Y.), 92, 32.

McCrea, P. C. (1957). Lancet, 1, 402

McMaster, P. D. (1942). “Harvey Lectures, 1941-42”, ser. 37, p. 227.

1953). In "The Nature and Significance of the Antibody Response: A Symposium held at the New York Academy of Medicine, March, 1951" (Section on Microbiology, Symposium No. 5), ed. A. M. Pappenheimer, p. 13 . Columbia University Press, New York.

Medawar, P. B. (1958). "Harvey Lectures, 1956-57", ser. 52, p. 144.

Mellors, R. C., Heimer, R., Corcos, J., and Korngold, L. (1959). J. exp. Med., 110, 875 .

Mongar, J. L., and Schild, H. O. (1957). J. Physiol. (Lond.), 135, 320.

Ortega, L. G., and Mellors, R. C. (1957). J. exp. Med., 106, 627.

Paterson, P. Y. (1960). Ibid., 111, 119.

Porter, R. R. (1950). Biochem. J., 46, 473.

Robbins, W. C., Holman, H. R., Deicher, H., and Kunkel, H. G. (1957). Proc. Soc. exp. Biol. (N.Y.), 96, 575

Rich, A. R. (1942). Bull. Johns Hopk. Hosp. 71, 123. - and Gregory, J. E. (1943). Ibid., 72, 65.

Riley, J. F., and West, G. B. (1953). J. Physiol. (Lond.), 120, 528.

Rivers, T. M., Sprunt, D. H., and Berry, G. P. (1933). J. exp. Med. $58,39$.

Roitt, I. M.. and Doniach, D. (1957). Proc. roy. soc. Med., 50, 958 (1959). In "Mechanisms of Hypersensitivity" (Henry

Ford Hospital International Symposium), ed. J. H. Shaffer, G. A. LoGrippo, and M. W. Chase, p. 325. Little, Brown and Co., Boston; Churchill, London.

Rose, H. M., Ragan, C., Pearce, E., and Lipman, M. O. (1948). Proc. Soc. exp. Biol. (N.Y.), 68, 1.

Rose, N. R., and Witebsky, E. (1956). J. Immunol., 76, 417.

Singer, J. M., and Plotz, C. M. (1956). Amer. J. Med., 21, 888.

Svartz, N., Carlson, L. A., Schlossmann, K., and Ëhrenberg, A. (1958). Acta med. scand., 160,87.

Taliaferro, W. H. (1949). Ann. Rev. Microbiol., 3, 159.

Tanaka, N., and Leduc, E. H. (1956). J. Immunol., 77, 198.

Uhr, J. W., Salvin, S. B., and Pappenheimer, A. M. (1957). J. exp. Med. 105, 11

Ungar, G. (1953). Int. Arch. Allergy, 4, 258

van Loghem, J. J. JR, van der Hart, M., Hijmans, W., and Schuit, H. R. E. (1958). Vox Sang. (Basel), 3, 203.

Vazquez, J. J., and Dixon, F. J. (1957). Lab. Invest., 6, 205. Vaughan, J. H., Ellis, P. J., and Marshall, H. (1958). J. Immunol.,

- and Harris, J. (1959). Arthr. and Rheum., 2, 51

Waksman, B. H. (1959). In "Cellular and Humoral Aspects of the Hypersensitive States: A symposium held at the New York. Academy of Medicine" (Section on Microbiology, Symposium $\rightrightarrows$ No. 9), ed. H. S. Lawrence, p. 167. Hoeber, New York; ஸे Cassell. London.

Waaler, E. (1940). Acta path. microbiol. scand., 17, 172.

White, R. G., Coons, A. H., and Connolly, J. M. (1955). J. exp. med., 102, 73 .

Witebsky, E., and Rose, N. R. (1956). J. Immunol., 76, 408

Wilson, G. S., and Miles, A. A. (1955a). "Topley and Wilson's Principles of Bacteriology and Immunity", 4th ed., p. 235. Arnold, London.

- - (1955b). Ibid., p. 242.

Ziff, M. (1957). J. chron. Dis., 5, 644. Brown, P., Lospalluto, J., Badin, J., and McEwen, C. (1956). $\overrightarrow{0}$ Amer. J. Med., 20, 500.

\section{Aspects immunologiques de la maladie rhumatismale RÉSUMÉ}

On considère les différentes réactions immunologiques $\vec{\varphi}$ que l'on peut reproduire expérimentalement chez $\omega$ l'homme ou l'animal. Celles-ci comprennent l'ana- $\vec{\omega}$ phylaxie, la réaction d'Arthus, l'hypersensibilité du type provoqué par la tuberculine et les réactions à la greffe 음 homologue. Par rapport à ces réactions immunologiques connues, on considère certaines lesions (telles que nodules $\vec{c}$ souscutanés) et certaines réactions sérologiques (telles $\mathbb{D}$ que celle de Rose-Waaler), et on conclue que les phéno- 0 mènes d'autoimmunisation jouent probablement un rôle $\mathbb{D}$ dans la pathogénie de la maladie rhumatismale.

\section{Aspectos imunológicos de la enfermedad reumatoide} SUMARIO

Se consideran las diferentes reacciones imunológicas reproducibles experimentalmente en los animales o en el hombre. Estas incluyen anafilaxia, reacción de Arthus, hipersensibilidad retardada del tipo de la porovocada por la tuberculina, y reacciones a los homoinjertos. En comparación con estas conocidas reacciones $\mathbb{Q}$ imunológicas se consideran ciertas lesiones (tales como $\overrightarrow{\vec{O}}$ los nódulos subcutáneos) y ciertas reacciones sero- $\frac{0}{3}$ lógicas (tales como la de Rose-Waaler). De dicho análisis se concluye que los fenómenos de autoimunización tienen probablemente cierta importancia en la patogenia de la enfermedad reumatoide. 